\title{
Method to Calculatethe Stress in Complex Welded Joints
}

\author{
Hernán HernándezHerrera ${ }^{\# 1}$ Rafael Goytisolo Espinosa ${ }^{\sharp 2}$ Juan José Cabello Eras ${ }^{\sharp 3}$. \\ Alexis Sagastume Gutiérrez ${ }^{\# 4}$ \\ ${ }^{\# 1}$ Faculty of Engineering, Universidad de la Costa. Barranquilla, Colombia \\ ${ }^{1}$ hhernand16@cuc.edu.co. \\ ${ }^{\# 2}$ Faculty of Engineering, Universidad de Cienfuegos. Cienfuegos, Cuba. \\ ${ }^{2}$ ragoyti@ucf.edu.cu \\ ${ }^{\# 3}$ Faculty of Engineering, Universidad de la Costa. Barranquilla, Colombia \\ jicabello2@cuc.edu.co. \\ ${ }^{\# 4}$ Faculty of Engineering, Universidad de la Costa. Barranquilla, Colombia \\ asagastu1@cuc.edu.co.
}

\begin{abstract}
This study presents a method to calculate the stress on the different components of complex welded joints to calculate the welded seam. The method is applied to a complex welded joint on an Ishaped beam, welded and reinforced with plates, in an overlap joint. The proposed method is validated by the Finite Element Method. Results show differences lower than 5\% between the proposed method and the Finite Element simulation, proving the applicability of the method to any complex welded joint.
\end{abstract}

Keywords:calculation, stress, finite element method, modelation, complex welded joints.

\section{INTRODUCCIÓN.}

Welding technologies stand asone of the most used technologies in the manufacturing of metal structures [1]. However, regardless of its widespread use, there are few studies discussing methods for calculating and designingwelded joints. Shigley emphasized the difficulty for engineers because of the limited scope and depth of the existing methods to calculate welded joints [2].

Themethods discussed in literatureof welded joints are too general,focusingtypical configurations, failing to discuss more complex welded joints. Some authors [2], [3], [4] discussed more complex welded joints using rather different models, in some cases resulting in contradictory.

The influence of technological parameters like the process development, the joint geometry and welding materials on the strength of welded joints was studied [5], [6], [7], [8], [9]. The main factors influencing weld joints failure are residual stress, local temperature effects and initial crack formations [10],[11], [12]. To evaluate the performance of cracksand forecast the lifespan of welded joints, fracture mechanics have been studied[13], [14], [15], [16], [17], [18].

Several researchers have discussed the mechanical strength related with the geometryof complex welded joints, for 2 Ishaped beams fillet welded under bending [19], open profile fillet welding under torsion [20], in both cases results were validated with Finite Elements Analyze models, also used to determinate the stress concentration factor in welded joints of different geometries [21], [22].

The analytical methods used to design welding joints have remain unchanged for decades. Since the simplifications used in analytical methods are well known, the use of high values of safety factors is rather frequent [23], causing the over dimensioning of welded joints. This study aims at developing a method to evaluate the distribution of the mechanical stress in the different parts of the welded seam in complex welded joints to more accurately calculate the stress on welded joints.

\section{MATERIALAND METHODS.}

The simplest of the welded joints is the fillet weld seam affected by transversal loads as shown in Fig. 1.

The stress and the stress concentrations in this joint are lower in the transverse seams than in the longitudinal ones [1], [2], [24].However, forcomplex welded joints is rather difficult to define how loads affect the different elements of the weld seam. 


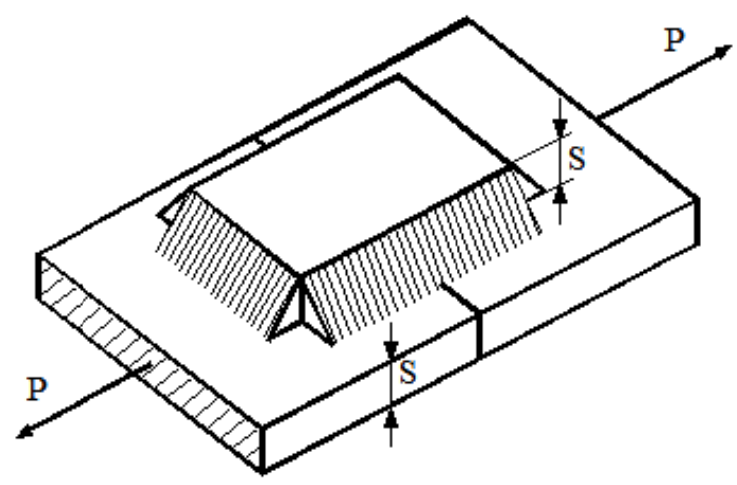

Fig. 1. Longitudinal and transverse fillet welding joint.

The basis of the proposed methods is the rigidity analysis [25].Fig. 2 shows two I shapedbeamsjoined with welded plates in the lateral, upper and lower surfaces. This configuration has awide range of applications to cover spans larger than the available beam longitudes[26].A normal load (NT), a transverse shear load (QT) and a bending moment (MFT) is applied to the welded joint.

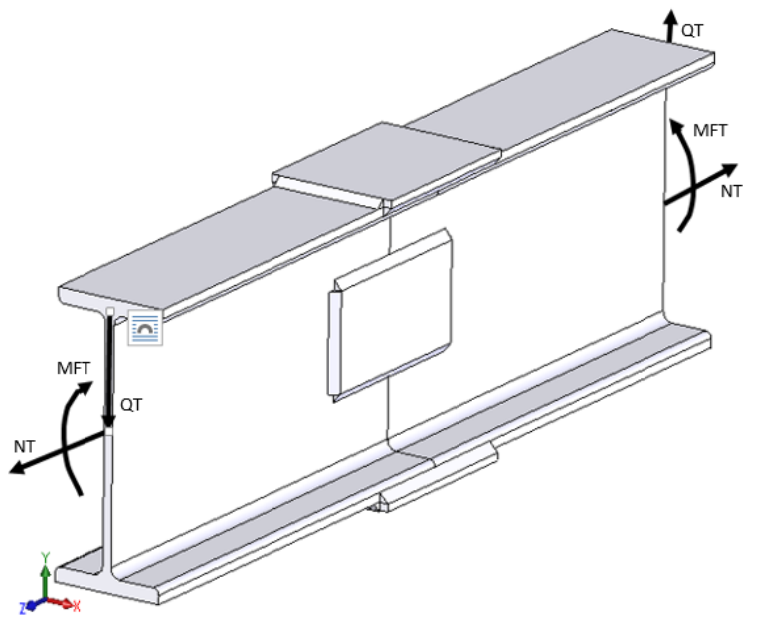

Fig. 2.Complex joint scheme to analyze.

The external loads are distributed between the three elements of the welded jointsee Fig. 3. However, there are no procedures or methods to define which component is supported by each of the welded joints elements in order to calculate the stresses of each welded seam.

The stress value of each element of the analyzed welded joint is determinedby applying the principle of superposition and distribution of internal forces, analyzing it for:

Axial force: NT, Shear force: QT, Bending moment: MFT

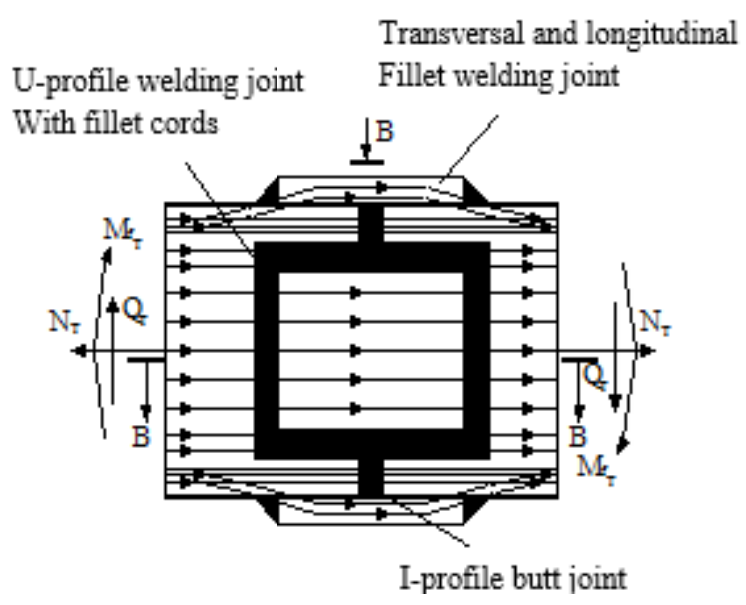

Fig. 3. Forces flow distribution between joint elements. 
A. Axial Force.

The force NT equals the three force elements of the joint:

$\mathrm{N}_{\mathrm{T}}=\mathrm{N}_{1}+\mathrm{N}_{2}+\mathrm{N}_{3}$

Where:

$\mathrm{N}_{\mathrm{T}}$ - Total axial force acting on joint.

$\mathrm{N}_{1}$ - Axial force supporting joint 1 .

$\mathrm{N}_{2}$ - Axial force supporting the top and bottom plates.

$\mathrm{N}_{3}$ - Axial force supporting lateral plates.

Under the axial force $\left(\mathrm{N}_{\mathrm{T}}\right)$, the welded joint deforms a magnitude $\varepsilon$. Each elementof the welded joint supports a fraction of the total load, which is directly proportional to the rigidity of its corresponding section:

$\varepsilon=\frac{\Delta l}{l}=\frac{N}{E \cdot A}$

and $\varepsilon_{1}=\varepsilon_{2}=\varepsilon_{3}$

$\frac{N_{1}}{E \cdot A_{1}}=\frac{N_{2}}{E \cdot A_{2}}=\frac{N_{3}}{E \cdot A_{3}}$

Replacing (3) into (1) and expressing $\mathrm{N}_{\mathrm{T}}=f\left(\mathrm{~N}_{1}\right)$, it gives:

$$
\begin{aligned}
& N_{T}=N_{1}+\frac{A_{2}}{A_{1}} N_{1}+\frac{A_{3}}{A_{1}} N_{1} \\
& N_{1}=\frac{N_{T}}{1+\frac{A_{2}}{A_{1}}+\frac{A_{3}}{A_{1}}}=\frac{N_{T} \cdot A_{1}}{A_{1}+A_{2}+A_{3}}
\end{aligned}
$$

Similarly, expressions for $\mathrm{N}_{2}$ and $\mathrm{N}_{3}$ can be obtained:

$$
\begin{aligned}
& N_{2}=\frac{N_{T} \cdot A_{2}}{A_{1}+A_{2}+A_{3}} \\
& N_{3}=\frac{N_{T} \cdot A_{3}}{A_{1}+A_{2}+A_{3}}
\end{aligned}
$$

In the case under assessment:

$A_{1}-$ Cross sectional area of the I shapedbeam.

$\mathrm{A}_{2}-$ Cross sectional area of both, the two upper and lower plates

$\mathrm{A}_{3}-$ Cross sectional area of the two lateral plates.

Fig. 4 shows the different dimensions considered in this study.

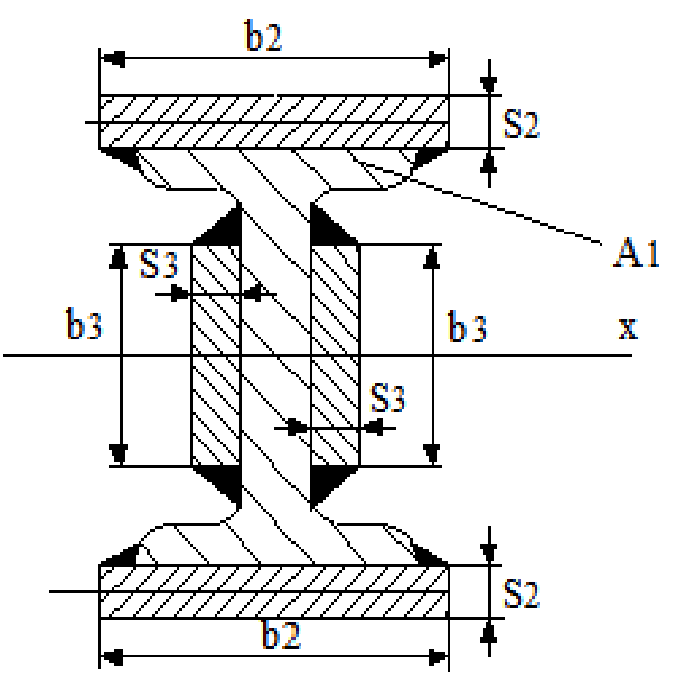

Fig. 4. Dimensions of welded joint elements. 


\section{B. Shear Force.}

Similar to $\mathrm{N}_{\mathrm{T}}$, the shear force $\left(\mathrm{Q}_{\mathrm{T}}\right)$ is:

$\mathrm{Q}_{\mathrm{T}}=\mathrm{Q}_{1}+\mathrm{Q}_{2}+\mathrm{Q}_{3}$

Where:

$\mathrm{Q}_{\mathrm{T}}$-Total shear force acting on joint.

$\mathrm{Q}_{1}$ - Shear force supporting joint 1 .

$\mathrm{Q}_{2}$ - Shear force supporting both, the top and bottom plates.

$\mathrm{Q}_{3}$-Shear force supporting the lateral plates.

Since the distortion caused in the section is the same for the three elements of the joint, the force acting on each element will be proportional to their shear rigidity.

$\frac{Q_{1}}{G \cdot A_{1}}=\frac{Q_{2}}{G \cdot A_{2}}=\frac{Q_{3}}{G \cdot A_{3}}$

Similarly to the axial forces:

$Q_{1}=\frac{Q_{T} \cdot A_{1}}{A_{1}+A_{2}+A_{3}}$

$Q_{2}=\frac{Q_{T} \cdot A_{2}}{A_{1}+A_{2}+A_{3}}$

$Q_{3}=\frac{Q_{T} \cdot A_{3}}{A_{1}+A_{2}+A_{3}}$

\section{Bending Moment}

The value of the total bending moment supporting each elements of the welded joint depends on the flexural rigidity. Similar to $\mathrm{N}_{T}$ and $\mathrm{Q}_{\mathrm{T}}$ :

$\mathrm{MF}_{\mathrm{T}}=\mathrm{M}_{1}+\mathrm{M}_{2}+\mathrm{M}_{3}$

From the differential equation of the elastic line:

$\mathrm{M}_{1}=\mathrm{E} \cdot \mathrm{Ix}_{1} \cdot \mathrm{y}_{1}{ }^{\prime \prime}$

$\mathrm{M}_{2}=\mathrm{E} \cdot \mathrm{Ix}_{2} \cdot \mathrm{y}_{2}{ }^{\prime \prime}$

$\mathrm{M}_{3}=\mathrm{E} \cdot \mathrm{Ix}_{3} \cdot \mathrm{y}_{3}^{\prime \prime}$

Since $\mathrm{y}_{1}=\mathrm{y}_{2}=\mathrm{y}_{3}$, where $\mathrm{y}_{1}{ }^{\prime}=\mathrm{y}_{2}{ }^{\prime}=\mathrm{y}_{3}{ }^{\prime}$ and $\mathrm{y}_{1}{ }^{\prime \prime}=\mathrm{y}_{2}{ }^{\prime \prime}=\mathrm{y}_{3}{ }^{\prime \prime}$ then.

$\frac{M_{1}}{E \cdot \mathrm{I} x_{1}}=\frac{M_{2}}{E \cdot \mathrm{I} x_{2}}=\frac{M_{3}}{E \cdot \mathrm{I} x_{3}}$

Combining equations 16 and 12 :

$M_{1}=\frac{M f_{T} \cdot \mathrm{I} x_{1}}{\mathrm{I} x_{1}+\mathrm{I} x_{2}+\mathrm{I} x_{3}}$

$M_{2}=\frac{M f_{T} \cdot \mathrm{I} x_{2}}{\mathrm{I} x_{1}+\mathrm{I} x_{2}+\mathrm{I} x_{3}}$

$M_{3}=\frac{M f_{T} \cdot \mathrm{I}_{3}}{\mathrm{I} x_{1}+\mathrm{I} x_{2}+\mathrm{I} x_{3}}$

Where:

$\mathrm{Ix}_{1}-$ Inertia moment of the Ishaped beam related to its centroid axis $\mathrm{X}$.

$\mathrm{Ix}_{2}$ - Inertia moment of the upper and lower plates in relation to the axis $\mathrm{X}$ (see Fig. 5).

$\mathrm{I} x_{2}=2 b_{2} \cdot S_{2}\left[\frac{3 h^{2}+6 h \cdot S_{2}+4 S_{2}^{2}}{12}\right]$ 


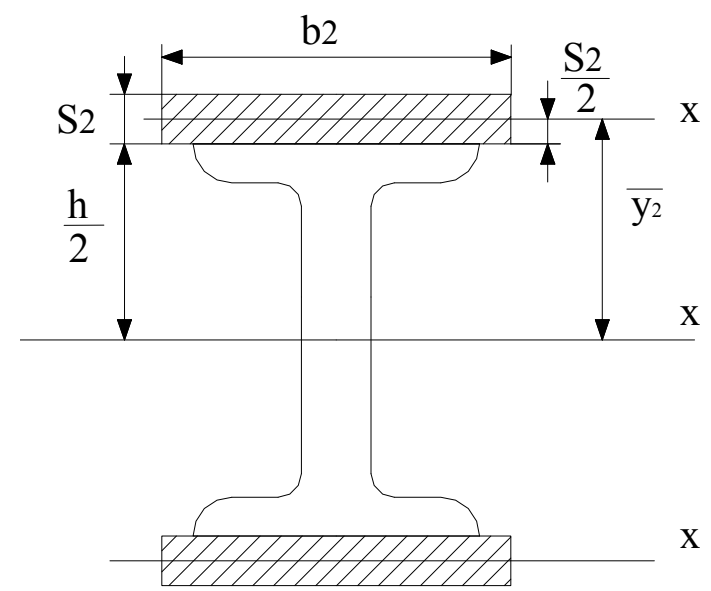

Fig. 5. Basic dimensions of the upper and lower plates.

$\mathrm{Ix}_{3}$ - Inertia moment of the lateral plates in relation to the axis X (see Fig. 6).

$\mathrm{I} x_{3}=2 \cdot \frac{1}{12} S_{3} b_{3}^{3}=\frac{S_{3} \cdot b_{3}^{3}}{6}$

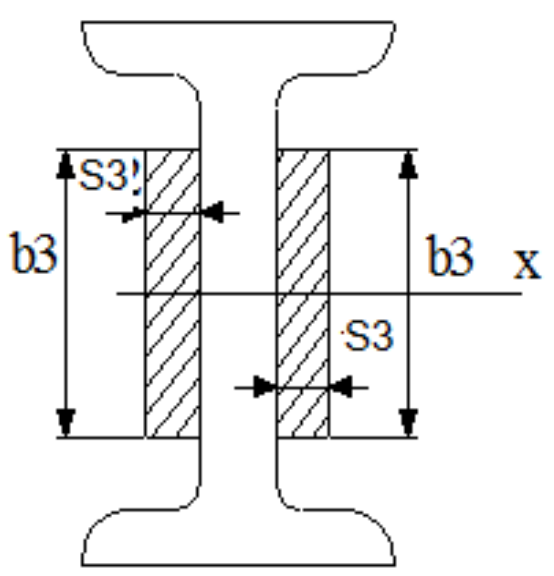

Fig. 6. Basic dimensions of the lateral plates.

D. Calculation of the stresscaused by the MFT.

From the above equations, the bending moment for the three elements of the welded jointiscalculated,

E. Stress caused by the bending moment $M_{1}$ in the joint of the Ishaped beam.

The bending moment causes traction and compression normal stress, proportional to the coordinate. They are calculated from the Navier equation

$\sigma_{y}=\frac{M_{1} \cdot y}{I x}$

The maximum stress is calculated as:

$\sigma_{M f} \max =\frac{M_{1} \cdot y \max }{I x}=\frac{M_{1}}{W x}$

F. Calculation of the stress on the top and bottom plates resulting from the moment $M_{2}$.

The top and bottom plates welded joint can be considered as a fillet welding joint under the action of different loads, as shown in Fig. 7. 


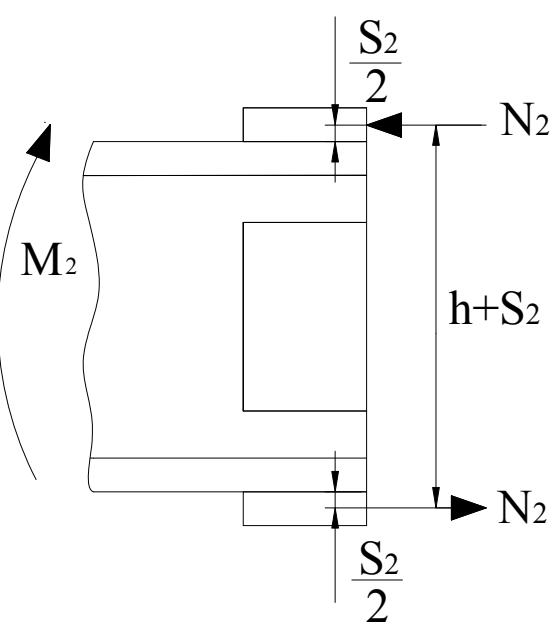

Figure 7. Stress on the welded joint fillet of the top and bottom plates.

Forces $\mathrm{N}_{2}$ acting on these platesis calculated as:

$$
\begin{aligned}
& M_{2}=N_{2} \cdot\left(h+S_{2}\right) \\
& N_{2}=\frac{M_{2}}{h+S_{2}} \\
& \sigma_{2}=\frac{N_{2}}{A_{2}}
\end{aligned}
$$

G. Stress caused by the bending moment $M_{1}$ in the lateral plates.

Lateralplates are affected by the bending moment $\mathrm{M}_{3}$, which is calculated with the Navier equation:

$\sigma_{3}=\frac{M_{3} \cdot y_{\max }}{2 \cdot I x_{3}}$

\section{H. Simulation of the stress with the Finite Element Method.}

To validate the proposed equations a complex welded joint under pure bending moment (see Fig.2), which is the most complex welded joint discussed in this study. First the proposed methodology is applied. Afterwards, a simulation based on the Finite Element Method is developed. The momentsapplied are shown in table I.

TABLE IMoments applied to the complex welded joint.

\begin{tabular}{|c|c|}
\hline Case & Momentvalue $(\mathrm{N} \cdot \mathrm{mm})$ \\
\hline 1 & $1,0 \cdot 10^{9}$ \\
\hline 2 & $1,5 \cdot 10^{9}$ \\
\hline 3 & $2,0 \cdot 10^{9}$ \\
\hline 4 & $2,5 \cdot 10^{9}$ \\
\hline 5 & $3,0 \cdot 10^{9}$ \\
\hline 6 & $4,0 \cdot 10^{9}$ \\
\hline
\end{tabular}

An IPN 300 profile (European Standard Beams) is selected as theIshaped beam. The top, bottom and lateral plates are square with $S_{2}$ and $S_{3}$ thickness of $8 \mathrm{~mm}$, the length of the lateral plates $\left(b_{3}\right)$ is $200 \mathrm{~mm}$ and the length of the top and bottom plates $\left(b_{2}\right)$ is of $145 \mathrm{~mm}$.

I. Calculation of the inertia moments of the welded joint components.

Inertia Moments.

$\mathrm{Ix}_{1}-$ moment of in relation to its centroid axis $\mathrm{X}$.

For anIPN 300 beamIx $_{1}=98.000 .000 \mathrm{~mm}^{4}$

Inertia moment of the upper and lower plates in relation to the axis $\mathrm{X}$.

$\mathrm{I} x_{2}=2 b_{2} \cdot S_{2}\left[\frac{3 h^{2}+6 h \cdot S_{2}+4 S_{2}^{2}}{12}\right]$ 
$\mathrm{I} x_{2}=55033493 \mathrm{~mm}^{4}$

Inertia moment of lateral plates in relation to the axis $\mathrm{X}$.

$\begin{aligned} \mathrm{I} x_{3} & =2 \cdot \frac{1}{12} S_{3} b_{3}^{3}=\frac{S_{3} \cdot b_{3}^{3}}{6} \\ \mathrm{I} x_{3} & =10.666 .666,67 \mathrm{~mm}^{4}\end{aligned}$

\section{RESULTS AND DISCUSSION.}

A. Total moment applied to the joint $\left(M_{T}\right)$.

$M_{T}=2 \cdot 10^{9} \mathrm{~N} \mathrm{~mm}$

Calculation of Moment $\left(\mathrm{M}_{1}, \mathrm{M}_{2}, \mathrm{M}_{3}\right)$.

$M_{1}=\frac{M_{T} \cdot \mathrm{I} x_{1}}{\mathrm{I} x_{1}+\mathrm{I} x_{2}+\mathrm{I} x_{3}}=1197310993 \mathrm{Nmm} M_{2}=\frac{M_{T} \cdot \mathrm{I} x_{2}}{\mathrm{I} x_{1}+\mathrm{I} x_{2}+\mathrm{I} x_{3}}=672369450 \mathrm{Nmm}$

$M_{3}=\frac{M_{T} \cdot \mathrm{I} x_{3}}{\mathrm{I} x_{1}+\mathrm{I} x_{2}+\mathrm{I} x_{3}}=130319555 \mathrm{~N} \mathrm{~mm}$

B. Calculation of the stress in the welded joint elements.

Force $\left(\mathrm{N}_{2}\right)$.

$$
\begin{aligned}
& M_{2}=N_{2} \cdot\left(h+S_{2}\right) \\
& N_{2}=\frac{M_{2}}{h+S_{2}}=2183017.74 \mathrm{~N}
\end{aligned}
$$

Stress $\left(\sigma_{1}\right)$.

$\sigma_{1}=\frac{M_{1} \cdot y_{\max }}{I x_{1}}=1832.61 \mathrm{MPa}$

Stress in the top and bottom plates $\left(\sigma_{2}\right)$.

$\sigma_{2}=\frac{N_{2}}{A_{2}}=1 \quad 783,91 \mathrm{MPa}$

Stress in the lateral plates $\left(\sigma_{3}\right)$.

$\sigma_{3}=\frac{M_{3} \cdot y_{\max }}{2 \cdot I x_{3}}=610 \mathrm{MPa}$

\section{Stress obtained by Finite Element Method.}

Fig. 8 shows the results obtained from the Finite Element Method simulation for the conditions used in the analytical assessment.

The welded join is simulated in Cosmos Design Star 4.0 software, a parabolic tetrahedral finite element, which give the best results because it can more easily generate a contour configuration [27],[28], [29].For each case a convergence between the previous and the current model is set to a $5 \%$ difference between the stress, ensuring that the stress valuesis independent of the mesh size[30].

For the third case the simulationare result in $\sigma_{1}$ equal to $1.854 \mathrm{MPa}, \sigma_{2}$ equal to $1.809 \mathrm{y}$ and $\sigma_{3}$ equal to 644 MPa.All values are between 2 and $5 \%$ difference to those obtained analytically. These results validate the proposed method for its application incomplex welded joints. 


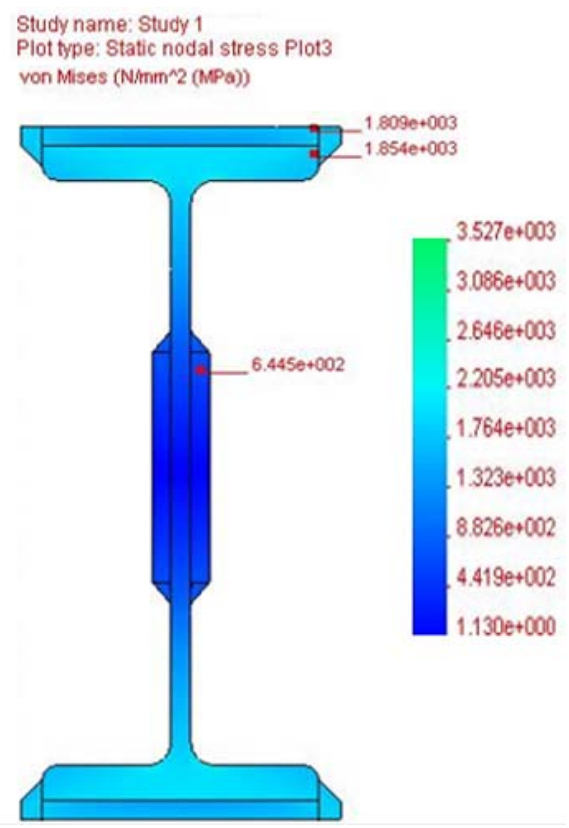

Fig. 8. Results obtainedin the Finite Element Method for a bending moment of $2 \cdot 10^{9} \mathrm{~N} \cdot \mathrm{mm}$

Table II shows the stress resulting from the analytic method and from the simulation.

TABLE II Comparison between analytical and Finite Element Method results.

\begin{tabular}{|c|c|c|c|c|c|c|}
\hline MomentN $\cdot \mathrm{mm}$ & $\sigma 1$ Analytic & $\sigma 1 \mathrm{MEF}$ & $\sigma 2$ Analytic & $\sigma 2$ MEF & $\sigma 3$ Analytic & $\sigma 3$ MEF \\
\hline $1 \cdot 10^{9}$ & 916 & 943 & 870 & 882 & 305 & 324 \\
\hline $1,5 \cdot 10^{9}$ & 1374 & 1401 & 1337 & 1347 & 458 & 472 \\
\hline $2 \cdot 10^{9}$ & 1832 & 1854 & 1783 & 1809 & 632 & 644 \\
\hline $2,5 \cdot 10^{9}$ & 2290 & 2328 & 2229 & 2239 & 764 & 778 \\
\hline $3 \cdot 10^{9}$ & 2748 & 2782 & 2675 & 2697 & 916 & 938 \\
\hline $4 \cdot 10^{9}$ & 3605 & 3698 & 3567 & 3575 & 1222 & 1248 \\
\hline
\end{tabular}

With the stress of each element ofthe complex welded joint is possibleto define the dimensions of the welded seam [19], [23], which allows to make an adequate design of the welded joint.

\section{CONCLUSION.}

The method proposed in this study allows to calculate the stress in the different components of complex welded joints, which in turn allows to more accurately calculate the dimensions of the welded seam. The method proposed can be applied to any complex welded joint.

\section{REFERENCES.}

[1] P.Kah and J. Martikainen, "Current trends in welding processes andmaterials: Improve in effectiveness". Reviews on Advanced Materials Science, vol. 30, No 2, pp.189-200, Sep. 2012

[2] J. Shigley and C. Mischkie,Diseño en Ingeniería Mecánica,5 th ed. Ed. Ciudad de México, México:Mc Graw Hill Interamericana,2001.

[3] V. Dobrovolski, Elementos de Máquinas. 3rd ed. Ed Moscú, URSS: MIR,1970.

[4] A. Hall, H. Lauglhin. Diseño de Máquinas.3rd ed. Madrid, España: Editorial: Dossat.1971.

[5] M.Leitner, T. Fössl, M. Stoschka and W. Eichlseder"Evaluation of fillet weld properties and fatigue behavior in dependence of welding parameters"Archives of Civil and Mechanical Engineering. vol. 11 No 3, pp 651-659,Dec.2011.

[6] J.Günther, P. M. Pilarski, G.Helfrich, H. Shen and K.Diepold. "Intelligent laser welding through representation, prediction, and control learning: An architecture with deep neural networks and reinforcement learning". Mechatronics, Vol. 34 No 1, pp. 1-11,Mar. 2016.

[7] A. Yuewei, S. Xinyu, P. Jiang, L. Peigen, and L. Yan Liu,Wei."Welded joints integrity analysis and optimization for fiber laser" Optics and Lasers in Engineering.vol. 86, pp 62-74, Nov. 2016.

[8] S. Shashi Kumar,A. Murugana and K. Ramachandran. "Influence of tool material on mechanical and microstructural properties of friction stir welded 316L austenitic stainless steel butt joints". Journal of Refractory Metals and Hard Materials. vol. 58, pp. 196205,Aug. 2016.

[9] L. Durán, Y. Aguilar, O. Hernández, V. Prado and F. Casanova."Efecto de la geometría de los depósitos de soldadura de recubrimiento en el desgaste de acero bajo al carbono en contacto con bagazo de caña de azúcar". Ingeniería y Universidad.vol. 17.No3, pp.127-141, Jun. 2013.

[10] Y. Haradaa, Y.Sada and Shinji Kumai. "Joining steel studs and steel plates by solid-state stud welding and estimation of temperature near the joint interface". Journal of Manufacturing Processes. vol. 23.pp. 75-82,Aug.2016.

[11] Y. Hyun and H. Kim, "High temperature crack growth behavior in a Cr-Mo steel weldment"International Journal of Engineering and Technology (IJET). vol. 7. No 5, pp. 1799-1804,Nov. 2015. 
[12] R. Shrestha, W. Kim, H. Park, and J Park. "Numerical Simulation of Similar and Dissimilar Materials Welding Process; Quantifications of Temperature, Stress, Strain and Deformation”. International Journal of Engineering Technology(IJET),vol. 7. No.1,pp 335-349,Mar. 2015.

[13] T.Sarikka, M.Ahonen, R.Mouginot, P.Nevasmaa, P.Karjalainen-Roikonen, U. Ehrnsten and H.Hanninen. "Microstructural, mechanical, and fracture mechanical characterization of SA 508-Alloy 182 dissimilar metal weld in view of mismatch state". International Journal of Pressure Vessels and Piping. vol. 145, pp. 13-22,Sept. 2016.

[14] R.Balokhonov, V.A. Romanova, S.A. Martynov, A.V. Zinoviev, O.S. Zinovieva, and E.E. Batukhtina. "A computational study of the microstructural effect on the deformation and fracture of friction stir welded aluminum". Computational Materials Science. vol. 116, pp. 2-10, Apr. 2016

[15] F. Yusof and M.F. Jamaluddin“Welding Defects and Implications on Welded Assemblies" Materials Science and Materials Engineering. vol. 6, pp. 125-134.May. 2014.

[16] M.Sulaiman, H.Nizam M. Shah, M.HaniffHarun and M. Nor FakhzanMohdKazim. "Defect inspection system for shape-based. Matching using two cameras".Journal of Theoretical and Applied Information Technology (JATIT). Vol. 61. No 2, pp. 288-297, Mar. 2014.

[17] V. Vaithiyanathan, B. Venkataraman and M. Anishin Raj "Weld defect detection in radiography based on Projection profile and RST invariant by using LVQ".Journal of Theoretical and Applied Information Technology (JATIT). vol. 34. No 1, pp 167-172,Dec. 2011.

[18] M. Xiangmeng, G. Qin, X and Bai. Z.Zou. "Numerical analysis of undercut defect mechanism in high speed gas tungsten arc welding".Journal of MaterialsProcessingTechnology.vol. 236,pp. 225-234.Oct. 2016.

[19] M. Prendes, M. Rodríguez, M. González and C. Aguado. "Modelación de Uniones Soldadas". Departamento de Construcción e Ingeniería de la fabricación. Universidad de Oviedo. España. Tech. Rep. 1-11.2014.

[20] H. Hernández Herrera, R. Goytisolo Espinosa, J.J. Cabello Eras and M. Balbis Morejón. "Stress in butt welded joints of open profiles under torsión" RevistaChilena de Ingeniería. vol. 23. No 4,pp. 638-646. Nov. 2015.

[21] B. Anupriya and D. K.Jagadeesan, "Shear strength of castellated beam with and without stiffeners using FEA (Ansys 14)". International Journal of Engineering and Technology (IJET), vol.6. No 4, pp. 1970-1981.Sep. 2014.

[22] F. Schoefs, M.Chevreuil, M. Cazuguel and O.Pasqualini,"Partial safety factor calibration from stochastic finite element computation of welded joint with random geometries”,Reliability Engineering and System Safety. vol. 155. Pp. 44-54.Nov. 2016.

[23] N. Arzola De La Peña, O. Araque De Los Ríos, “Chord profile influence on the fatigue failure of a t-butt weld joint”, RevistaChilena de Ingeniería. vol. 22.No. 2, pp. 196-204,Apr. 2014

[24] H. Hernández Herrera, R. Goytisolo Espinosa, J. Moya Rodríguez, I. M. Jackson. "Perfeccionamiento de los esquemas de análisis y del cálculo de las tensiones en las uniones soldadas a solape con costuras de filete longitudinal y transversal". Ingeniería Mecánica. vol. 8 No 1, pp. 79-86.Jan. 2005.

[25] S.J. Yan, S.K. Ong, A.Y.C. Nee "Stiffness analysis of parallelogram-type parallel manipulators using a strain energy method", Robotics and Computer-Integrated Manufacturing,vol. 37, 13-22, Feb. 2016.

[26] Guía de diseño para edificios con estructura de acero, Diseño de uniones Tomo 13, Ed, Madrid, España:"Instituto técnico de la estructura en acero ITEA.

[27] E. Martínez, M. Estrems. "Desarrollo de un modelo matemático de diferencias finitas para el análisis del campo de temperaturas en la soldadura por arco de chapas finas de acero inoxidable". Revista de Metalurgia, vol. 46. No. 6, pp. 511-519. Dec. 2010.

[28] S. E. McCaslin, P. S. Shiakolas, B. H. Dennis and K. Lawrence, "Closed-form stiffness matrices for higher order tetrahedral finite elements", Advances in Engineering Software, vol. 44,pp. 75-79, Feb. 2012.

[29] S. Duczek,, F.Duvigneau, U.Gabbert, "The finite cell method for tetrahedral meshes", Finite Elements in Analysis and Design, vol. 121, pp. 18-32, Jul. 2016.

[30] T. Chau, F.Besnier,"Numerical simulation of welding in shipbuilding",WIT Transactions on The Built Environment, vol. 68. pp 320.Dec 2003

\section{AUTHOR PROFILE}

Hernan Hernández Herrera is working as professor at Universidad de la Costa. His interest areas are applied mechanics and energy efficiency.

Rafael Goytisolo Espinosa is working as professor at Universidad de Cienfuegos. His interest areas isapplied mechanics.

Juan Jose Cabello Eras is working as professor at Universidad de la Costa. His interest areas are applied mechanics and energy efficiency.

Alexis Sagastume Gutiérrez is working as professor at Universidad de la Costa. His interest areas are energy efficiency and thermal engineering. 